\title{
TINDAKAN PENCEGAHAN KARIES GIGI PADA SISWA SEKOLAH DASAR BERDASARKAN TEORI HEALTH BELIEF MODEL
}

\author{
PREVENTION OF DENTAL CARIES IN ELEMENTARY SCHOOL STUDENTS \\ BASED ON THE THEORY OF HEALTH BELIEF MODEL
}

\author{
Lidia Septianingtias Setiari, Muji Sulistyowati \\ Departemen Promosi Kesehatan dan Ilmu Perilaku, \\ Fakultas Kesehatan Masyarakat, Universitas Airlangga, Surabaya. \\ Email: lidlidialidio@gmail.com
}

\begin{abstract}
Dental caries is one of the serious health problem in school age children. The maintenance of dental and oral health need to be done early in the prevention of dental caries. This study was conducted to analyze the application of Health Belief Model theory on dental caries prevention in elementary school students. This research was quantitative study with a cross-sectional approach. Sample were fifth grade student at SDN Kedurus 1 Surabaya amount to 53 students and taken by simple random sampling. The independent variable were perceived susceptibility, perceived severity, perceived benefits, perceived barriers, self-efficacy and cues to action. The dependent variable of this study was action in the prevention of dental caries. Quantitative data was analyzed using Spearman correlation test and logistic regression. The respondent action to prevent dental caries was good. There was a correlation between perceived susceptibility, perceived severity, perceived benefits, perceived barriers, self-efficacy and cues to action with action in preventing dental caries. This research concluded that perceived susceptibility was the most influencing factor in preventing dental caries. It was suggested to increase the effort of promotive and preventive in school so that the students can more diligent in doing dental caries prevention action.
\end{abstract}

Keywords: health belief model, dental caries, behavior of students

\begin{abstract}
Abstrak: Karies gigi merupakan salah satu masalah kesehatan serius pada anak usia sekolah. Upaya pemeliharaan kesehatan gigi dan mulut sejak dini perlu dilakukan dalam pencegahan terjadi nya karies gigi. Penelitian ini dilakukan untuk menganalisis aplikasi teori Health Belief Model terhadap tindakan pencegahan karies gigi pada siswa sekolah dasar. Penelitian ini dilaksanakan dengan rancangan cross sectional dengan pendekatan secara kuantitatif. Sampel penelitian ini adalah siswa kelas 5 di SDN Kedurus 1 Surabaya sebanyak 53 orang dan diambil dengan cara simpel random sampling. Variabel independen penelitian ini adalah kerentanan, keseriusan, manfaat, hambatan, kemampuan diri serta isyarat untuk bertindak terhadap pencegahan karies gigi. Variabel dependen penelitian ini adalah tindakan dalam pencegahan karies gigi. Data kuantitatif dianalisis dalam bentuk tabulasi dengan menggunakan uji spearman correlation dan regresi logistic. Tindakan responden untuk mencegah karies gigi sudah baik. Terdapat adanya hubungan antara kerentanan, keseriusan, manfaat, hambatan, kemampuan diri serta isyarat untuk bertindak terhadap pencegahan karies gigi dengan tindakan dalam mencegah karies gigi. Penelitian ini menyimpulkan kerentanan merupakan faktor yang paling memengaruhi tindakan dalam mencegah karies gigi. Disarankan untuk meningkatkan upaya promotif dan preventif di sekolah agar siswa lebih rajin dalam melakukan tindakan pencegahan karies gigi
\end{abstract}

Kata kunci: health belief model, karies gigi, tindakan siswa

\section{PENDAHULUAN}

Karies gigi merupakan salah satu gangguan kesehatan gigi dan mulut. Karies gigi terjadi akibat adanya kerusakan jaringan keras gigi yang meliputi enamel, dentin, dan sementum. Proses kerusakan gigi ini dimulai adanya proses demineralisasi yang diikuti kerusakan zat organik sehingga terjadi perkembangan bakteri. Bakteri masuk ke dalam jaringan gigi melalui lapisan dentin hingga ke bagian pulpa (Kumala, 2006). Tidak hanya gigi orang dewasa saja yang dapat mengalami karies gigi, melainkan pada anak-anak baik gigi susu maupun gigi permanen juga dapat mengalami karies gigi. Anak dengan usia 6-14 tahun merupakan 
usia yang rawan dan kritis yang dapat terkena karies gigi dan pada usia tersebut mempunyai sifat khusus yaitu masa dimana terjadi peralihan dari gigi susu ke gigi permanen (Wong, 2003).

Menurut data WHO menyatakan bahwa sebesar $60-90 \%$ anak-anak banyak yang mengalami karies gigi dimana prevalensi tertinggi pada anak-anak yang ada di Negara Amerika dan kawasan Eropa. Sedangkan, menurut WHO global oral health, prevalensi indeks karies gigi global antara anak usia 12 tahun dan rata-rata 1,6 gigi yang berarti rata-rata per orang mengalami kerusakan gigi lebih dari satu gigi (WHO, 2003). Sedangkan di Indonesia sebesar 29,8\% kelompok umur 12 tahun menderita karies gigi (Depkes, 2007). Usia anak-anak yang mengalami karies gigi saat ini salah satunya dipengaruhi oleh faktor perilaku masyarakat. Kurangnya kesadaran akan pentingnya merawat kesehatan gigi dan mulut dapat mengakibatkan produktivitas karena pengaruh sakit yang dirasakan. Sisa makanan yang menempel pada gigi yang tidak dibersihkan dapat menyebabkan terjadi nya kerusakan gigi yang mengakibatkan gigi menjadi keropos, berlubang dll. Dampak yang ditimbulkan akibat karies gigi yang terjadi pada anak-anak akan menghambat proses perkembangan pada anak salah satunya adalah tingkat kecerdasan anak semakin menurun yang apabila terjadi terus menerus dan dalam jangka waktu yang panjang akan memengaruhi kualitas hidup anak. Menurut Listiono (2012), salah satu penyebab terjadi nya karies gigi pada seseorang akibat kebiasaan mengonsumsi makanan yang manis dan lengket serta rasa malas dan kesalahan cara menyikat gigi serta jarang memeriksakan kesehatan gigi setiap 6 bulan sekali juga dapat menyebabkan karies gigi.

Upaya pemeliharaan kesehatan gigi dan mulut sebaiknya dilakukan sedini mungkin sehingga karies gigi dapat dicegah agar tidak sampai terjadi pada anak-anak. Sekolah merupakan salah satu lingkungan yang dapat dijadikan sebagai tempat untuk mengalahkan promosi kesehatan gigi. Teknik dan metode yang dapat dilakukan di sekolah terkait dengan promosi kesehatan gigi dapat dilakukan oleh guru melalui ceramah umum, media elektronik, media cetak seperti poster serta menggunakan media di luar ruangan melalui spanduk (Notoatmodjo, 2010). Usia sekolah dasar merupakan saat yang ideal untuk dilakukan upaya-upaya kesehatan gigi dan mulut karena pada usia sekolah dasar merupakan awal mula tumbuh gigi permanen dan merupakan kelompok risiko tinggi karies gigi (Dinkes Kota Surabaya, 2015).

Salah satu bentuk untuk menjaga kesehatan gigi dan mulut agar tetap sehat adalah dengan melatih kemampuan motorik seorang anak, termasuk diantaranya dengan menggosok gigi. Kemampuan menggosok gigi secara baik dan benar merupakan faktor cukup penting untuk pemeliharaan gigi dan mulut (Riyanti, 2013). Waktu yang optimal untuk membersihkan gigi dilakukan setelah makan di pagi hari dan sebelum tidur malam. Menyikat gigi setelah makan di pagi hari bertujuan untuk membersihkan sisa-sisa makanan yang menempel setelah makan dan sebelum tidur malam bertujuan untuk membersihkan sisa-sisa makanan yang menempel setelah makan malam (Potter, 2005).

Berdasarkan Riskesdas 2013, persentase penduduk yang mempunyai masalah kesehatan gigi dan mulut sebesar $25,9 \%$. Jawa Timur menempati urutan ke tiga yang memiliki peningkatan masalah gigi dan mulut tertinggi pada tahun 2007 sebesar 20,3\% menjadi $28,6 \%$ di tahun 2013 . Proporsinya pada kelompok umur 10-14 tahun yang merupakan usia anak sekolah sebesar 25,2\% sedangkan dalam kebiasaan menyikat gigi sebesar 7,3\% yang menyikat gigi dengan benar pada tahun 2007 dan menurun menjadi 2,3\% pada tahun 2013 (Kemenkes RI, 2014).

Menurut profil kesehatan kota Surabaya tahun 2015 berdasarkan hasil pemeriksaan kesehatan gigi untuk siswa SD/MI dikota Surabaya menunjukkan hasil UKGS (Usaha Kesehatan Gigi Sekolah) dari 219.450 siswa SD/MI yang diperiksa, siswa SD/MI yang memerlukan perawatan kesehatan gigi sebanyak 71.715 siswa, dan yang mendapatkan perawatan sebesar 51.901 siswa atau sebesar 72,37\%. Apabila dibandingkan dengan tahun sebelumnya dengan responden yang berbeda 
menunjukkan adanya peningkatan cakupan siswa SD/MI yang mendapatkan perawatan gigi sebesar 3,64\%. Berdasarkan hal tersebut masih banyak siswa usia sekolah yang mengalami masalah kesehatan gigi dan mulut salah satunya adalah karies gigi sehingga masih banyak siswa usia sekolah yang membutuhkan perawatan.

Puskesmas Kedurus yang berada di Kecamatan Karang Pilang merupakan salah satu puskesmas yang masuk dalam 10 besar puskesmas yang memiliki banyak sekolah binaan. Pada tahun 2015 dalam upaya kesehatan gigi sekolah puskesmas ini memiliki 20 sekolah binaan dari jumlah murid SD/MI yang diperiksa sebanyak 6.327 siswa dan yang perlu mendapatkan perawatan sebanyak 2.238 siswa dengan persentase sebesar 35,37\% (Dinkes Kota Surabaya, 2015).

SDN Kedurus 1 Surabaya merupakan salah satu sekolah binaan yang dimiliki oleh puskesmas Kedurus. Berdasarkan survey awal di SDN Kedurus 1 Surabaya yang dilakukan pada siswa kelas 5 karena siswa sudah memasuki usia 10 tahun dan pada usia tersebut anak sudah dapat diajak berkomunikasi dengan baik. Diperoleh data sebanyak $48 \%$ siswa mengalami lebih dari satu gigi karies. sedangkan dari hasil wawancara pada salah satu guru UKS di SDN Kedurus 1 Surabaya kegiatan penyuluhan, pemeriksaan gigi dan mulut serta melakukan sikat gigi masal hanya dilakukan selama setahun sekali yang dilakukan oleh puskesmas.

Teori Health Belief Model (HBM) merupakan suatu bentuk model teori yang digunakan untuk memberikan dorongan kepada masyarakat untuk melakukan tindakan kesehatan yang positif salah satunya adalah tindakan pencegahan penyakit karies gigi. Teori ini menyatakan bahwa individu dalam mengambil tindakan pencegahan penyakit atau untuk berperilaku sehat dipengaruhi oleh perceived susceptibility, perceived severity, perceived benefits, perceived barriers, self efficacy dan cues to action yang dapat memengaruhi seseorang untuk dapat berperilaku sehat. Perceived susceptibility berkaitan dengan kerentanan dirinya terhadap penyakit, perceived severity berkaitan dengan tingkat keseriusan penyakit yang dirasakan, perceived benefits dan barriers penilaian atau keyakinan individu akan adanya keuntungan dan kerugian yang dirasakan apabila melakukan tindakan pencegahan penyakit, self efficacy berkaitan dengan keyakinan diri dalam individu akan kemampuan untuk melakukan tindakan serta cues to action yang menjelaskan adanya keyakinan mengenai tanda-tanda yang mendorong seseorang untuk melakukan tindakan pencegahan penyakit. Teori Health Belief Model merupakan model yang dapat menjelaskan mengenai perilaku sehat yang dilakukan oleh individu dengan sangat baik (Glanz dkk, 2008).

Sebelum individu melakukan suatu tindakan pencegahan karies gigi terdapat faktor pemodifikasi yang dapat memengaruhi tindakan yang akan dilakukan individu tersebut antara lain usia, jenis kelamin, sosial ekonomi, pengetahuan dan pengalaman pribadi. Berdasarkan latar belakang, maka peneliti tertarik untuk melakukan penelitian tentang tindakan dalam pencegahan karies gigi dengan menggunakan konsep teori Health Belief Model.

Tujuan dalam penelitian ini adalah menganalisis tindakan pencegahan karies gigi pada siswa sekolah dasar dengan menggunakan teori Health Belief Model yang meliputi kerentanan terhadap karies gigi, keseriusan terhadap karies gigi, manfaat terhadap pencegahan karies gigi, hambatan terhadap pencegahan karies gigi, kemampuan diri terhadap pencegahan karies gigi serta isyarat untuk bertindak terhadap pencegahan karies gigi.

\section{METODE}

Jenis penelitian ini merupakan observasional analitik dengan pendekatan secara kuantitatif dimana rancang bangun penelitian tergolong cross sectional. Penelitian ini dilakukan di SDN Kedurus 1 Surabaya pada bulan Mei-November 2016. Populasi dalam penelitian ini sebanyak 117 siswa kelas 5 sekolah dasar dan diambil sampel sebanyak 53 siswa. Penelitian ini dilakukan pada siswa kelas 5 sekolah dasar yang rata-rata berusia 10 tahun hal ini dikarenakan berdasarkan Riskesdas tahun 2013 proporsi pada kelompok usia 10-14 
tahun memiliki urutan kedua dimana usia tersebut masuk dalam usia anak sekolah yang mengalami peningkatan masalah gigi dan mulut salah satunya karies gigi sebesar $25,2 \%$.

Teknik pengumpulan data dalam penelitian ini dengan wawancara melalui kuesioner. Instrument kuesioner digunakan untuk mengetahui tindakan siswa dalam mencegah karies gigi melalui variabel yang terdapat dalam teori HBM. Data primer didapat dengan menggunakan instrument penelitian kuesioner yang dikaji kepada responden sebagai sampel dalam penelitian.

Pengumpulan data dilakukan sendiri oleh peneliti, dengan memberikan inform consent dan meminta persetujuan berupa tanda tangan orang tua yang mengijinkan anaknya untuk menjadi responden penelitian kemudian memberitahu cara dan waktu

Tabel 1. Distribusi Responden Menurut Variabel Teori Health Belief Model terhadap Karies Gigi.

\begin{tabular}{|c|c|c|c|}
\hline Variabel & Kriteria & $\mathbf{N}$ & $\%$ \\
\hline \multirow{3}{*}{$\begin{array}{l}\text { Kerentanan } \\
\text { Terhadap } \\
\text { Karies Gigi }\end{array}$} & Rentan & 38 & 71,7 \\
\hline & Tidak & 15 & 28,3 \\
\hline & Rentan & & \\
\hline \multirow{2}{*}{$\begin{array}{l}\text { Keseriusan } \\
\text { Terhadap } \\
\text { Karies Gigi }\end{array}$} & Parah & 26 & 49,06 \\
\hline & Tidak Parah & 27 & 50,94 \\
\hline \multirow{3}{*}{$\begin{array}{l}\text { Manfaat } \\
\text { Terhadap } \\
\text { Pencegahan } \\
\text { Karies gigi }\end{array}$} & Manfaat & 18 & 34,0 \\
\hline & Tidak & 35 & 66,0 \\
\hline & Manfaat & & \\
\hline \multirow{4}{*}{$\begin{array}{l}\text { Hambatan } \\
\text { Terhadap } \\
\text { Pencegahan } \\
\text { Karies Gigi }\end{array}$} & Hambatan & 25 & 47,2 \\
\hline & Tidak & 28 & 52,8 \\
\hline & Hambatan & & \\
\hline & & & \\
\hline \multirow{4}{*}{$\begin{array}{l}\text { Kemampuan } \\
\text { Diri Terhadap } \\
\text { Pencegahan } \\
\text { Karies Gigi }\end{array}$} & Mampu & 20 & 37,7 \\
\hline & Tidak & 33 & 62,3 \\
\hline & Mampu & & \\
\hline & & & \\
\hline \multirow{5}{*}{$\begin{array}{l}\text { Isyarat untuk } \\
\text { Bertindak } \\
\text { Terhadap } \\
\text { Pencegahan } \\
\text { Karies Gigi }\end{array}$} & Terdorong & 34 & 64,15 \\
\hline & Tidak & 19 & 35,85 \\
\hline & Terdorong & & \\
\hline & & & \\
\hline & & & \\
\hline \multirow{3}{*}{$\begin{array}{l}\text { Tindakan } \\
\text { Pencegahan } \\
\text { Karies Gigi }\end{array}$} & Melakukan & 31 & 58,5 \\
\hline & Tidak & 22 & 41,5 \\
\hline & Melakukan & & \\
\hline
\end{tabular}

pengisian kuesioner kepada responden dan memberikan penjelasan setiap soal kuesioner, sehingga diharapkan diperoleh jawaban yang lebih objektif. Pada waktu pengisian kuesioner siswa yang terpilih menjadi responden dikumpulkan di dalam satu ruang kelas dan mengisi kuesioner sendiri dengan dipandu peneliti. Data sekunder diperoleh saat pengumpulan data yang masih berhubungan dengan objek penelitian. Data sekunder diperoleh dari studi literatur yang terkait dengan penelitian ini, jurnal maupun referensi dari sumber lain yang relevan dengan penelitian ini.

Analisis data dalam penelitian ini menggunakan 3 analisis yaitu univariat, bivariat, multivariat. Analisis univariat yang disajikan dalam bentuk tabel agar dapat dilihat distribusi frekuensi atau bedanya proporsi masing-masing variabel yang diteliti dan selanjutnya untuk dianalisis. Analisis bivariat disajikan dalam bentuk tabel dengan menggunakan uji Spearman Correlation, sedangkan untuk analisis multivariate menggunakan regresi logistik.

\section{HASIL PENELITIAN}

Berdasarkan penelitian yang dilakukan mengenai aplikasi teori Health Belief Model terhadap tindakan pencegahan karies gigi pada siswa sekolah dasar didapatkan hasil sebagai berikut.

Penjelasan mengenai distribusi responden menurut variabel teori Health Belief Model terhadap karies gigi pada Tabel 1 dijelaskan sebagai berikut. Pada variabel kerentanan yang dirasakan terhadap karies gigi dijelaskan bahwa lebih dari sebagian responden memiliki rasa rentan terhadap karies gigi yaitu sebanyak 38 orang $(71,7 \%)$. Responden yang merasa rentan beranggapan apabila jarang menyikat gigi dapat menyebabkan terjadi nya penyakit karies gigi.

Distribusi responden pada variabel keseriusan yang dirasakan terhadap karies gigi dijelaskan bahwa separuh dari responden merasa karies gigi adalah penyakit yang tidak parah atau tidak terlalu serius terhadap kesehatannya dengan jumlah responden yaitu sebanyak 27 orang $(50,94 \%)$. Responden yang beranggapan 
karies gigi bukan penyakit yang serius berpendapat apabila terkena karies gigi tidak akan mengganggu aktivitas mereka seperti sekolah.

Pada variabel manfaat yang dirasakan dalam melakukan tindakan pencegahan terhadap karies gigi dijelaskan bahwa sebagian besar responden merasa tidak manfaat dalam melakukan tindakan pencegahan karies gigi. Jumlah responden yang didapatkan yaitu sebanyak 35 orang $(66,0 \%)$. Responden beranggapan bahwa salah satu upaya mencegah terjadi nya penyakit karies gigi dengan melakukan tindakan berkumur-kumur dengan air putih setelah makan-makanan manis tidak bermanfaat untuk mencegah terjadi nya karies gigi.

Variabel hambatan yang dirasakan untuk melakukan tindakan pencegahan karies gigi dalam penelitian ini dijelaskan bahwa sebagian besar responden tidak merasa hambatan dalam melakukan tindakan pencegahan karies gigi sebanyak 36 orang (67,92\%). Hal ini dikarenakan responden menganggap bahwa menggunakan pasta gigi yang rasanya pedas tidak akan menjadi kan hambatan bagi responden untuk melakukan tindakan menyikat gigi.

Distribusi pada variabel kemampuan diri responden untuk melakukan tindakan pencegahan terjadi nya penyakit karies gigi dijelaskan bahwa lebih dari sebagian responden merasa tidak mampu dalam melakukan tindakan mencegah karies gigi dengan jumlah responden sebesar 33 orang $(62,3 \%)$. Responden yang merasa tidak mampu dalam mencegah karies gigi beranggapan bahwa untuk memeriksakan gigi setiap 6 bulan sekali tidak mampu dilakukan responden untuk mencegah terjadi nya penyakit karies gigi pada dirinya.

Terdapat dua faktor yang memengaruhi responden untuk melakukan tindakan pencegahan karies gigi yaitu yang pertama faktor yang berasal dari dalam diri individu itu sendiri dan ke dua faktor yang berasal dari luar diri individu diantaranya berasal dari orang tua, guru, tenaga kesehatan, media cetak dan media elektronik.

Berdasarkan beberapa faktor yang berasal dari luar diri individu tersebut didapatkan hasil bahwa faktor terbesar pada variabel isyarat dalam bertindak untuk mendorong responden melakukan tindakan pencegahan karies gigi dalam penelitian ini berasal dari orang tua dengan jumlah responden sebanyak 51 orang $(96,23 \%)$. Pada Tabel 1 juga menjelaskan bahwa lebih dari sebagian besar responden merasa terdorong untuk melakukan tindakan pencegahan terhadap terjadi nya penyakit karies gigi sebanyak 34 orang $(64,15 \%)$.

Tindakan dalam penelitian ini merupakan praktek yang telah dilakukan oleh responden dalam upaya mencegah terjadi nya penyakit karies gigi. Tindakan dalam mencegah karies gigi terdapat dua respons yaitu tindakan melakukan pencegahan dan tidak melakukan tindakan pencegahan.

Pada penelitian ini menjelaskan bahwa lebih dari sebagian responden sudah memiliki tindakan yang baik untuk melakukan tindakan dalam mencegah terjadi nya penyakit karies gigi yang ditujukan pada tabel 1 dengan jumlah responden sebanyak 31 orang $(58,5 \%)$. Tindakan yang paling banyak dilakukan oleh responden dalam upaya mencegah terjadi nya penyakit karies gigi yang pertama yaitu melakukan tindakan menyikat gigi dengan menggunakan pasta gigi dan tindakan yang kedua dengan menyikat seluruh bagian gigi baik luardalam serta atas-bawah.

Hubungan variabel kerentanan terhadap karies gigi dengan tindakan dalam mencegah karies gigi pada Tabel 2 menunjukkan hasil analisis bahwa terdapat 29 orang $(54,7 \%)$ yang merasa rentan terhadap karies gigi dan melakukan tindakan yang baik dalam mencegah karies gigi. Sedangkan di antara responden ada 2 orang $(3,8 \%)$ yang merasa tidak rentan dengan karies gigi dan melakukan tindakan yang baik untuk mencegah karies gigi. Hasil uji statistik diperoleh nilai $\mathrm{p}=0,000$ artinya ada hubungan antara kerentanan terhadap karies gig dengan tindakan dalam mencegah karies gigi. Nilai koefisien korelasi spearman sebesar 0,538 yang berarti ada hubungan yang cukup kuat antara kerentanan terhadap karies gigi dengan tindakan dalam mencegah karies gigi.

Pada variabel hubungan antara keseriusan terhadap karies gigi dengan 
Tabel 2. Analisis Hubungan antara Variabel Health Belief Model dengan Tindakan dalam Mencegah Karies Gigi.

\begin{tabular}{|c|c|c|c|c|c|c|c|}
\hline \multirow{3}{*}{ Variabel } & \multirow{3}{*}{ Kriteria } & \multicolumn{4}{|c|}{$\begin{array}{c}\text { Tindakan Mencegah } \\
\text { Karies Gigi }\end{array}$} & \multirow{3}{*}{ Sig. } & \multirow{3}{*}{$\begin{array}{l}\text { Spearman } \\
\text { Correlation }\end{array}$} \\
\hline & & \multicolumn{2}{|c|}{ Tidak } & \multicolumn{2}{|c|}{ Iya } & & \\
\hline & & $\mathbf{N}$ & $\%$ & $\mathbf{N}$ & $\%$ & & \\
\hline \multirow{2}{*}{$\begin{array}{l}\text { Kerentanan Terhadap } \\
\text { Karies Gigi }\end{array}$} & Rentan & 9 & 17 & 29 & 54,7 & \multirow{3}{*}{0,000} & \multirow{3}{*}{0,538} \\
\hline & Tidak Rentan & 13 & 24,5 & 2 & 3,8 & & \\
\hline Total & & 22 & 41,5 & 31 & 58,5 & & \\
\hline \multirow{2}{*}{$\begin{array}{l}\text { Keseriusan Terhadap } \\
\text { Karies Gigi }\end{array}$} & Parah & 6 & 11,3 & 20 & 37,7 & \multirow{3}{*}{0,010} & \multirow{3}{*}{0,353} \\
\hline & Tidak Parah & 16 & 30,2 & 11 & 20,8 & & \\
\hline Total & & 22 & 41,5 & 31 & 58,5 & & \\
\hline \multirow{2}{*}{$\begin{array}{l}\text { Manfaat Terhadap } \\
\text { Pencegahan Karies Gigi }\end{array}$} & Manfaat & 3 & 5,7 & 15 & 28,3 & \multirow{3}{*}{0,008} & \multirow{3}{*}{0,362} \\
\hline & Tidak Manfaat & 19 & 35,8 & 16 & 30,2 & & \\
\hline Total & & 22 & 41,5 & 31 & 58,5 & & \\
\hline \multirow{2}{*}{$\begin{array}{l}\text { Hambatan Terhadap } \\
\text { Pencegahan Karies Gigi }\end{array}$} & Hambatan & 2 & 3,8 & 23 & 43,4 & \multirow{3}{*}{0,000} & \multirow{3}{*}{0,643} \\
\hline & Tidak Hambatan & 20 & 37,7 & 8 & 15,1 & & \\
\hline Total & & 22 & 41,5 & 31 & 58,5 & & \\
\hline \multirow{2}{*}{$\begin{array}{l}\text { Kemampuan Diri } \\
\text { Terhadap Pencegahan } \\
\text { Karies Gigi }\end{array}$} & Mampu & 3 & 5,7 & 17 & 32,1 & \multirow{3}{*}{0,002} & \multirow{3}{*}{0,419} \\
\hline & Tidak Mampu & 19 & 35,8 & 14 & 26,4 & & \\
\hline Total & & 22 & 41,5 & 31 & 58,5 & & \\
\hline \multirow{2}{*}{$\begin{array}{l}\text { Isyarat untuk Bertindak } \\
\text { Terhadap Pencegahan } \\
\text { Karies Gigi }\end{array}$} & Terdorong & 8 & 15,1 & 26 & 49,1 & \multirow{3}{*}{0,000} & \multirow{3}{*}{0,488} \\
\hline & Tidak Terdorong & 14 & 26,4 & 5 & 9,4 & & \\
\hline Total & & 22 & 41,5 & 31 & 58,5 & & \\
\hline
\end{tabular}

tindakan dalam mencegah karies gigi. Tabel 2 menjelaskan hasil analisis hubungan yang menunjukkan bahwa sebanyak 20 orang $(37,7 \%)$ yang merasa parah atau serius terhadap karies gigi dan melakukan tindakan yang baik dalam mencegah karies gigi, sedangkan di antara responden ada 6 orang $(11,3 \%)$ yang merasa parah atau serius dengan karies gigi tetapi tidak melakukan tindakan yang baik untuk mencegah karies gigi. Hasil uji statistik diperoleh nilai $\mathrm{p}=0,010$ artinya ada hubungan antara keseriusan terhadap karies gigi dengan tindakan dalam mencegah karies gigi. Nilai koefisien korelasi spearman sebesar 0,353 yang berarti ada hubungan yang tidak cukup kuat antara keseriusan terhadap karies gigi dengan tindakan dalam mencegah karies gigi.
Hubungan antara manfaat terhadap pencegahan karies gigi dengan tindakan dalam mencegah karies gigi dijelaskan pada tabel 2 hasil analisis hubungan yang menunjukkan bahwa 19 orang $(35,8 \%)$ yang merasa tidak manfaat dalam upaya mencegah karies gigi dan tidak melakukan tindakan yang baik dalam mencegah karies gigi, sedangkan di antara responden ada 3 orang $(5,7 \%)$ yang merasa manfaat dalam mencegah karies gigi tetapi tidak melakukan tindakan yang baik dalam mencegah karies gigi. Hasil uji statistik diperoleh nilai $\mathrm{p}=$ 0,008 artinya ada hubungan antara manfaat terhadap pencegahan karies gigi dengan tindakan dalam mencegah karies gigi. Nilai koefisien korelasi spearman sebesar 0,362 yang berarti ada hubungan yang tidak cukup kuat antara manfaat terhadap pencegahan karies gigi dengan tindakan dalam mencegah karies gigi. 
Pada tabel 2 juga menjelaskan hasil analisis hubungan antara hambatan terhadap pencegahan karies gigi dengan tindakan dalam mencegah karies gigi bahwa ada 23 orang $(43,3 \%)$ yang merasa ada hambatan dalam melakukan tindakan pencegahan karies gigi tetapi tetap melakukan tindakan yang baik untuk mencegah karies gigi. Sedangkan di antara responden ada 2 orang $(3,8 \%)$ yang merasa ada hambatan untuk melakukan tindakan pencegahan karies gigi dan tidak melakukan tindakan yang baik untuk mencegah karies gigi. Hasil uji statistik diperoleh nilai $p=0,000$ yang artinya ada hubungan antara hambatan terhadap pencegahan karies gigi dengan tindakan dalam mencegah karies gigi. Nilai koefisien korelasi spearman sebesar 0,643 yang menujukan ada hubungan yang cukup kuat antara hambatan terhadap pencegahan karies gigi dengan tindakan dalam mencegah karies gigi.

Pada variabel kemampuan diri terhadap pencegahan karies gigi pada tabel 2 dijelaskan hasil analisis hubungan antara kemampuan diri terhadap pencegahan karies gigi dengan tindakan dalam mencegah karies gigi bahwa terdapat 19 orang $(35,8 \%)$ yang merasa tidak mampu dalam melakukan tindakan pencegahan karies gigi dan tidak melakukan tindakan yang baik untuk mencegah karies gigi. Sedangkan di antara responden ada 3 orang $(5,7 \%)$ yang merasa mampu untuk melakukan tindakan pencegahan karies gigi tetapi tidak melakukan tindakan yang baik untuk mencegah karies gigi. Hasil uji statistik diperoleh nilai $\mathrm{p}=0,002$ artinya ada hubungan antara kemampuan diri terhadap pencegahan karies gigi dengan tindakan dalam mencegah karies gigi dengan nilai koefisiensi korelasi spearman sebesar 0,419 yang berarti ada hubungan yang cukup kuat antara kemampuan diri terhadap pencegahan karies gigi dengan tindakan dalam mencegah karies gigi.

Variabel isyarat untuk bertindak terhadap pencegahan karies gigi pada penelitian dijelaskan pada tabel 2 diperoleh hasil analisis hubungan antara isyarat untuk bertindak terhadap pencegahan karies gigi dengan tindakan dalam mencegah karies gigi di SDN Kedurus 1 didapatkan bahwa sebanyak 26 orang $(49,1 \%)$ merasa terdorong untuk melakukan tindakan mencegah karies gigi dan tetap melakukan tindakan yang baik untuk mencegah karies gigi, sedangkan 5 orang $(9,4 \%)$ diantaranya merasa tidak terdorong untuk melakukan tindakan mencegah karies gigi tetapi mereka tetap melakukan tindakan yang baik untuk mencegah terjadi nya karies gigi. Hasil uji statistik diperoleh nilai $p=0,000$ artinya ada hubungan antara isyarat untuk bertindak terhadap pencegahan karies gigi dengan tindakan dalam mencegah karies gigi. Nilai koefisiensi korelasi spearman sebesar 0,488 yang artinya ada hubungan yang cukup kuat antara isyarat untuk bertindak terhadap pencegahan karies gigi dengan tindakan dalam mencegah karies gigi.

Berdasarkan hasil uji statistik yang telah diuji untuk melihat variabel yang paling berpengaruh dalam melakukan tindakan pencegahan karies gigi dilakukan dengan menggunakan model regresi logistik. Variabel dependen dalam penelitian ini adalah tindakan dalam mencegah karies gigi sedangkan variabel independennya adalah variabel kerentanan terhadap karies gigi, keseriusan terhadap karies gigi, manfaat terhadap pencegahan karies gigi, hambatan terhadap pencegahan karies gigi, kemampuan diri terhadap pencegahan karies gigi serta isyarat untuk bertindak terhadap pencegahan karies gigi. Setelah dilakukan uji regresi logistik dapat diketahui bahwa variabel yang memengaruhi tindakan dalam mencegah karies gigi di SDN Kedurus 1 Surabaya adalah pada variabel kerentanan terhadap karies gigi dengan (sig. 0,022 dengan $\operatorname{Exp}(B)=6,632)$ yang dapat disimpulkan bahwa semakin merasa rentan terhadap karies gigi maka orang tersebut akan memiliki peluang 6,632 kali menjadi baik dalam melakukan tindakan pencegahan karies gigi.

Pada penelitian ini mengenai tindakan pencegahan karies gigi pada siswa sekolah dasar berdasarkan teori Health Belief Model (HBM) menunjukkan bahwa tindakan untuk mencegah terjadi nya karies gigi sudah dilakukan responden dengan baik. Hal ini diperkuat dengan jawaban responden mengenai tindakan yang paling banyak dilakukan responden untuk mencegah 
terjadi nya karies gigi dengan menyikat gigi menggunakan pasta gigi dan menyikat seluruh permukaan gigi baik atas-bawah maupun luar-dalam.

Tindakan merupakan reaksi yang ditunjukkan seseorang terhadap rangsangan yang berasal dari luar. Tindakan atau praktik dilakukan atas pengetahuan serta respons sikap yang dimiliki sesorang terhadap suatu objek. Perilaku seseorang terbentuk dipengaruhi oleh pengetahuan, sikap serta tindakan. Terdapat tiga perilaku kesehatan yaitu, perilaku sehat, perilaku sakit dan perilaku orang sakit. Penelitian ini hanya melihat perilaku sehat yang dimiliki responden untuk melakukan tindakan pencegahan karies gigi. Perilaku sehat merupakan suatu kegiatan yang dilakukan seseorang untuk meningkatkan serta mempertahankan kesehatannya sehingga seseorang tersebut tidak sampai terserang penyakit. Apabila seseorang dapat melakukan perilaku sehat ini maka karies gigi dapat dicegah sehingga seseorang dapat meningkatkan kesehatannya.

Pada penelitian ini menunjukkan bahwa ada hubungan yang cukup kuat antara kerentanan yang dirasakan dengan tindakan dalam mencegah karies gigi. Persentase kerentanan yang dirasakan responden terhadap karies gigi di SDN Kedurus 1 Surabaya menjawab rentan dengan beranggapan bahwa jarang menyikat gigi menyebabkan seseorang rentan terkena karies gigi sedangkan responden yang tidak merasa rentan dengan karies gigi berpendapat bahwa cara menyikat gigi tidak benar dapat memengaruhi terjadi nya lubang gigi. Menurut penelitian yang dilakukan Ningsih (2013) disimpulkan bahwa terdapat kecenderungan peningkatan persentase kejadian karies gigi pada anak dengan kebiasaan menggosok gigi yang salah dibandingkan yang benar. Cara menggosok gigi yang baik adalah dengan membersihkan seluruh bagian gigi mulai dari permukaan gigi bagian dalam, luar dan pengunyahan harus disikat dengan gerakan vertikal dan lembut (Wong, 2008). Sedangkan responden yang merasa rentan terhadap karies gigi tetap melakukan tindakan yang baik dalam pencegahan karies gigi.
Pada penelitian ini variabel mengenai keseriusan atau keparahan yang dirasakan dengan tindakan dalam mencegah karies gigi menunjukkan ada hubungan akan tetapi hubungan tersebut tidak cukup kuat artinya apabila seseorang memiliki rasa keseriusan yang tinggi terhadap karies gigi tidak semuanya akan melakukan tindakan yang baik untuk mencegah karies gigi tetapi hanya sebagian besar yang akan melakukan tindakan pencegahan karies gigi. Keseriusan yang dirasakan responden apabila terkena karies gigi berpendapat bahwa penyakit karies gigi bukan penyakit yang parah atau serius yang dapat memengaruhi kesehatan gigi dan mulutnya.

Responden yang merasa bahwa penyakit karies gigi bukan penyakit yang parah atau serius berpendapat bahwa apabila terkena karies gigi tidak akan mengganggu aktivitas mereka seperti sekolah. Padahal, karies gigi mengakibatkan penurunan produktivitas karena pengaruh sakit yang dirasakan. Hal ini terjadi karena menurunnya jaringan pendukung gigi serta karies gigi yang dibiarkan menjadi sumber infeksi yang mengakibatkan beberapa penyakit sistemik (Rhamadhan, 2010). Sedangkan responden yang merasa apabila terkena karies gigi merupakan penyakit yang serius dan parah tetap melakukan tindakan yang baik dalam mencegah karies gigi.

Keseriusan atau keparahan yang dirasakan seseorang terhadap suatu penyakit akan mendorong seseorang tersebut untuk mencari pengobatan dan melakukan pencegahan penyakit (Glanz dkk, 2008). Dalam penelitian ini keseriusan atau keparahan yang dirasakan responden akibat dampak yang timbul dari karies gigi memengaruhi rasa kecemasan dan kekhawatiran yang akan terjadi pada kesehatannya sehingga responden mau melakukan tindakan pencegahan agar terhindar dari karies gigi.

Kerentanan dan keseriusan yang dirasakan seseorang akan memengaruhi seseorang untuk mengambil suatu tindakan yang dilakukan agar dapat melakukan pencegahan penyakit atau pengobatan. Tindakan yang akan dilakukan dapat dipengaruhi oleh manfaat yang akan 
dirasakan apabila seseorang melakukan tindakan tersebut. Pada penelitian ini variabel manfaat yang dirasakan dengan tindakan dalam mencegah karies gigi menujukan ada hubungan akan tetapi kekuatan hubungan tersebut tidak cukup kuat. Artinya apabila seseorang merasa manfaat yang akan dirasakan dari suatu tindakan yang akan dilakukan tidak terlalu besar maka untuk melakukan tindakan pencegahan tersebut akan semakin rendah. Pada penelitian ini menjelaskan bahwa responden merasa melakukan tindakan yang baik dalam pencegahan karies gigi bukan hal yang bermanfaat bagi kesehatannya hal ini diperkuat dengan jawaban responden yang menganggap dengan berkumur-kumur dengan air putih setelah makan-makanan manis tidak bermanfaat untuk mencegah terjadi nya karies gigi.

Berdasarkan teori HBM ini manfaat yang dirasakan lebih menentukan tindakan yang akan diambil seseorang (Glanz dkk, 2008). Keuntungan atau manfaat yang akan didapatkan akan merangsang sesorang untuk melakukan tindakan yang menguntungkan bagi dirinya (Notoatmodjo, 2010). Disimpulkan bahwa respons positif memiliki peran yang penting untuk seseorang dalam mengambil suatu keputusan yang baik untuk kesehatannya. Apabila seseorang merasa manfaat yang dirasakan tidak terlalu besar maka mereka cenderung tidak melalukan tindakan yang baik dalam pencegahan karies gigi. Sehingga perlunya meningkatkan kesadaran responden untuk memotivasi agar responden melakukan tindakan pencegahan karies gigi dengan cara memberikan penyuluhan terkait keuntungan dan kekurangan apabila melakukan tindakan yang baik dalam mencegah karies gigi.

Tindakan yang akan diambil seseorang pada umumnya lebih dipengaruhi oleh manfaat yang dirasakan daripada hambatan yang ditemukan. Pada penelitian ini variabel mengenai hambatan yang dirasakan dengan tindakan dalam mencegah karies gigi menunjukkan ada hubungan yang cukup kuat. Artinya semakin rendah hambatan yang dirasakan seseorang maka untuk melakukan suatu tindakan pencegahan akan semakin tinggi. Pada penelitian ini responden merasa tidak ada hambatan untuk melakukan tindakan pencegahan karies gigi diperkuat dengan jawaban responden yang merasa penggunaan pasta gigi yang rasanya pedas tidak menghambat responden untuk tidak menyikat gigi.

Menurut Machfoedz dan Suryani (2006) ada dua keyakinan yang dimiliki seseorang yaitu pertimbangan antara keuntungan atau yang dirasakan dan kerugian atau hambatan yang dirasakan yang memungkinkan seseorang tersebut akan melakukan tindakan pencegahan. Hambatan yang ditemukan akan memengaruhi besar kecilnya kemungkinan usaha yang akan dilakukan seseorang. Apabila hambatan yang dirasakan cukup besar maka kemungkinan seseorang untuk melakukan tindakan yang baik akan semakin kecil. Akan tetapi apabila hambatan yang dirasakan kecil maka kemungkinan seseorang untuk melakukan tindakan yang baik akan besar.

Seseorang untuk melakukan suatu tindakan diperlukan keyakinan diri bahwa mereka mampu untuk melakukan tindakan tersebut. Pada penelitian ini variabel antara kemampuan diri dengan tindakan dalam mencegah karies gigi menunjukkan ada hubungan akan tetapi hubungan tersebut tidak cukup kuat yang artinya apabila seseorang memiliki rasa kemampuan diri yang tinggi untuk melakukan tindakan pencegahan tidak semua orang akan melakukannya tetapi hanya sebagian saja yang akan melakukan tindakan yang baik dalam mencegah karies gigi. Pada penelitian ini responden menjawab tidak mampu untuk melakukan tindakan pencegahan terhadap karies gigi. Hal ini diperkuat dengan jawaban responden yang berpendapat bahwa responden tidak mampu untuk memeriksakan gigi ke dokter gigi setiap 6 bulan sekali sebagai upaya pencegahan terjadinya karies gigi.

Responden yang merasa tidak mampu untuk melakukan tindakan yang baik memiliki kecenderungan untuk tidak melakukan tindakan yang baik dalam mencegah karies gigi. Seseorang untuk melakukan perilaku dipengaruhi oleh pemikiran bahwa perilaku tersebut memiliki manfaat untuk dirinya atau tidak, jika seseorang memiliki pemikiran merasa tidak mampu untuk melakukan perilaku baru, 
maka perilaku yang baru tersebut tidak anak dilaksanakan (Glanz dkk, 2008).

Responden yang merasa tidak mampu dalam melakukan tindakan pencegahan karies gigi berpendapat bahwa mereka merasa tidak mampu menyikat gigi sebelum tidur malam setiap hari. Waktu menggosok gigi yang efektif adalah saat malam sebelum tidur. Menggosok gigi sebelum tidur penting untuk dilakukan karena produksi air liur yang kurang saat tidur serta ketika tidur malam sisa-sisa makanan yang tidak dibersihkan dapat meningkatkan interaksi dengan bakteri yang apabila hal tersebut berlangsung lama dapat menyebabkan lubang atau karies gigi (Potter, 2005). Penelitian yang sejalan yang dilakukan oleh Setiyawati (2012) berpendapat ada hubungan yang bermakna antara kebiasaan menggosok gigi sebelum tidur malam dengan karies gigi. Sehingga perlu imbauan untuk guru dan orang tua untuk membiasakan anak menggosok gigi sebelum tidur malam sejak usia sekolah.

Keyakinan yang dirasakan seseorang untuk melakukan tindakan selain dipengaruhi oleh kemampuan diri dapat pula karena ada dorongan atau tanda-tanda yang diperoleh dari luar individu untuk melakukan suatu tindakan. Pada penelitian ini mengenai isyarat untuk bertindak dengan tindakan dalam mencegah karies gigi menunjukkan ada hubungan yang cukup kuat yang artinya semakin tinggi dorongan yang diterima seseorang maka akan semakin besar pula dorongan untuk melakukan tindakan pencegahan karies gigi. Hal ini dibuktikan dengan jawaban responden yang merasa terdorong untuk melakukan tindakan pencegahan karies gigi dengan faktor dorongan tersebut terbesar berasal dari orang tua.

Peran orang tua di lingkungan tempat tinggal responden sangat diperlukan serta dapat memengaruhi perubahan perilaku yang akan ditiru oleh anaknya. Orang tua yang mengasuh anak sejak kecil sehingga orang tua dapat membantu anak untuk mengubah perilaku dan melatih anak untuk membiasakan diri sejak dini menjaga kesehatan dan kebersihan gigi dan mulut untuk mencegah karies gigi (Maulani dan Enterprise, 2005). Orang tua harus mempelajari cara menggosok gigi yang baik bersama anak, mengajarkan, mengawasi serta memandu anak untuk menggosok gigi hingga anak mampu bertanggung jawab atas kebersihan giginya sendiri (Hockenberry dan Wilson, 2007).

Isyarat untuk bertindak diperlukan seseorang sebelum melakukan suatu tindakan yang berasal dari faktor eksternal misalnya melalui media massa, nasihat anggota keluarga, guru atau teman dan faktor internal misalnya gejala dari penyakit yang dialami individu itu sendiri (Glanz dkk, 2008). Perilaku seseorang yang terbentuk tergantung pada informasi yang diterima saat melakukan interaksi sosial. Jika informasi yang didapat benar maka seseorang akan melakukannya dengan benar demikian juga sebaliknya. Sehingga lingkungan sosial mempunyai peran penting untuk mendorong seseorang dalam melakukan perubahan perilaku (Notoatmodjo, 2007).

Sehingga dapat disimpulkan bahwa seseorang yang memperoleh dorongan yang tinggi dapat meyakinkan seseorang untuk mengambil sebuah keputusan untuk melakukan suatu tindakan. Jadi semakin besar dorongan yang positif yang diterima responden maka semakin yakin pula responden untuk melakukan tindakan yang baik dalam mencegah karies gigi.

Berdasarkan analisis yang telah dilakukan didapatkan bahwa perceived susceptibility atau kerentanan yang dirasakan terhadap karies gigi merupakan faktor yang paling dominan untuk memengaruhi seseorang melakukan tindakan dalam pencegahan karies gigi. Dapat diartikan semakin seseorang merasa rentan terhadap karies gigi maka orang tersebut akan menjadi lebih baik untuk melakukan tindakan pencegahan karies gigi.

Upaya promosi kesehatan perlu ditingkatkan dengan cara melalui salah satu faktor dari teori HBM yaitu Cues to Action atau isyarat untuk bertindak yang berasal dari orang tua, guru dan petugas kesehatan agar lebih memperhatikan health education dengan memberikan informasi serta melakukan upaya persuasif (ajakan) yang dapat memengaruhi responden untuk melakukan tindakan yang baik dalam mencegah terjadi nya karies gigi. Apabila 
hal ini dilakukan dengan baik maka derajat kesehatan siswa terutama di SDN Kedurus 1 ini akan meningkat.

\section{KESIMPULAN}

Secara keseluruhan aplikasi teori HBM ini dapat memengaruhi tindakan pencegahan karies gigi pada siswa sekolah dasar. Variabel kerentanan yang dirasakan responden terhadap karies gigi merupakan faktor yang memiliki peluang paling besar untuk memengaruhi tindakan dalam mencegah karies gigi. Pada penelitian ini dijelaskan kerentanan yang dirasakan siswa apabila jarang menyikat gigi dapat menyebabkan gigi berlubang. Sedangkan Tindakan responden dalam melakukan tindakan pencegahan karies gigi sudah baik.

\section{DAFTAR PUSTAKA}

Budisuari, M, Oktarina, Makrajab, M. 2010. Hubungan Pola Makan dan Kebiasaan Menyikat Gigi dengan Kesehatan Gigi dan Mulut (Karies) Di Indonesia. Jurnal. Pusat Penelitian dan Pengembangan Sistem dan Kebijakan Kesehatan. Jakarta. Tersedia di $<$ http://ejournal.litbang.depkes.go.id/ index.php/hsr/article/view/2760/1518> [Senin, 23 Januari 2017].

Depkes RI. 2007. Usaha Kesehatan Sekolah di Tingkat Sekolah Dasar. Direktorat Jenderal Komunitas. Jakarta.

Dinkes Kota Surabaya. 2015. Profil Kesehatan Kota Surabaya Tahun 2015. Seleksi Pelayanan Kesehatan. Surabaya. Tersedia di <http://www.depkes.go.id/ resources/download/profil/Profil Kab. Kota_2015/3578_Jatim_Kota_ Surabaya_2015.pdf $>$ [22 Juli 2016].

Edelman C.L., \& Mandle C.L. 2006. Health Promotion: Throughout the Life Span. St. Louis. Mosby.

Glanz, K., Rimer, B. \& Viswanath, K. 2008. Health Behavior and Health Education: Theory, Research and Practice 4th edition. San Fra United States of America: Jossey-Bass.
Hockenberry M., \& Wilson, D. 2007. Wong's Nursing Care of Infants and Children. St. Louis. Mosby Elsevier

Kemenkes RI. 2014. Infodatin (Pusat Data dan Informasi Kementerian Kesehatan RI) Situasi Kesehatan Gigi dan Mulut. Jakarta Selatan

Kumala, P. 2006. Kamus Saku Kedokteran Dorland. Jakarta: EGC

Listiono, B. 2012. Kesehatan Gigi dan Mulut. Tersedia di $<\mathrm{http}$ ://www.litbang. tangerangkota.go.id/index.PHP/detail_ kesehatan_gigi_mulut> [8 Juni 2016].

Machfoedz, I., Suryani E. 2006. Pendidikan Kesehatan Bagian dari Promosi Kesehatan. Yogyakarta: F Tranaya.

Maulani, C., \& Enterprise J. 2005. Kiat Merawat Gigi Anak Panduan Orang Tua dalam Merawat dan Menjaga Kesehatan Gigi Bagi Anak-anaknya. Jakarta: PT. Elex Media Komunikasi.

Ningsih, D. 2013. Gambaran Perilaku Menggosok Gigi terhadap Kejadian Karies Gigi pada Anak Usia Sekolah Dasar di Wilayah Kerja Puskesmas Sidemen, Kecamatan Sidemen, Kabupaten Karangasem, pada Juni-Juli 2013. Jurnal. Universitas Udaya. Bali. Tersedia di< ojs.unud.ac.id/index.php/eum/article/ download/12685/8670> [Senin, 23 Januari 2017].

Notoatmodjo, S. 2007. Promosi Kesehatan \& Ilmu Perilaku. Jakarta: Rineka Cipta.

Notoatmodjo, S. 2010. Ilmu Perilaku Kesehatan. Jakarta: Rineka Cipta.

Potter, P. 2005. Buku Ajaran Fundamental Keperawatan Konsep, Proses dan Praktik. Jakarta: EGC.

Rhamadhan, A.G. 2010. Serba-Serbi Kesehatan Gigi dan Mulut. Jakarta: Bukune.

Riyanti, E. 2013. Hubungan Pendidikan Penyikatan Gigi dengan Tingkat Kebersihan Gigi dan Mulut Siswa-Siswi Sekolah Dasar Islam Terpadu (SDiT) Imam Bukhori. Skripsi. Universitas Padjajaran. Bandung. Diakses $<$ http:// repository.unpad.ac.id $>$ [Jumat, 10 Juni 2016]. 
Setiari, L. 2017. Aplikasi Teori Health Belief Model terhadap Perilaku Pencegahan Karies Gigi pada Siswa Sekolah Dasar. Skripsi. Universitas Airlangga. Surabaya.

Setiyawan, R. 2012. Hubungan Kebiasaan Menggosok Gigi Sebelum Tidur Malam dengan Karies pada Anak Sekolah di Madrasah Ibtidaiyah Al-Istiqomah Tangerang. Skripsi. Universitas Indonesia. Depok. Diakses melalui<http://lib.ui.ac.
id/file?file=digital/20301362-S42020 Rahayu\%20Setiyawan.pdf $>$ [Senin, 30 Januari 2017].

WHO. 2003. The World Oral Health Report. Tersedia di<http://www.who.int/oral health/media/en/orh-report03- en.pdf $>$ [Selasa, 7 Juni 2016].

Wong, D.I. 2003.Pedoman Klinis Keperawatan Pediatrik. Edisi 4. Jakarta: EGC.

Wong, D.I. 2008. Buku Ajar Keperawatan Pediatrik Edisi 6. Jakarta: EGC. 